ISSN 1392-3196 / e-ISSN 2335-8947

Zemdirbyste-Agriculture, vol. 100, No. 4 (2013), p. 409-416

DOI $10.13080 /$ z-a.2013.100.052

\title{
Morphological traits and genetic diversity of differently overwintered oilseed rape (Brassica napus L.) cultivars
}

\author{
Algimantas PAULAUSKAS ${ }^{1}$, Milda JODINSKIENE ${ }^{2}$, Loreta GRICIUVIENE ${ }^{1}$, \\ Judita ŽUKAUSKIENE ${ }^{1}$, Egle PETRAITIENE ${ }^{3}$, Irena BRAZAUSKIENE ${ }^{3}$ \\ ${ }^{1}$ Vytautas Magnus University \\ Vileikos 8, Kaunas, Lithuania \\ ${ }^{2}$ Institute of Botany, Nature Research Centre \\ Akademijos 2, Vilnius, Lithuania \\ E-mail: milda.jodinskiene@botanika.lt \\ ${ }^{3}$ Institute of Agriculture, Lithuanian Research Centre for Agriculture and Forestry \\ Instituto 1, Akademija, Kèdainiai distr., Lithuania
}

\begin{abstract}
Winter oilseed rape is an important crop grown in many countries for its valuable oil and protein. One of the main problems of cultivating rapeseed in northern countries is winter survival. The objective of this study was to assess morphological traits and genetic diversity of eleven cultivars of winter oilseed rape (Brassica napus L.) grown in experimental fields and to determine the correlation between phenotypic variation, deoxyribonucleic acid (DNA) polymorphism and overwintering characteristics. Oilseed rape stand density, height of growth point from the soil surface, thickness of root neck as well as the number of developed leaves per plant were observed for morphological traits analysis. The number of owerwintered plants was evaluated. The genetic variability of 11 oilseed rape cultivars was evaluated by random amplified polymorphic DNA (RAPD) screening 14 primers, 9 of them being polymorphic and used for further analysis. A total of 84 reproducible RAPD bands were identified among 134 individuals, 73 of the detected DNA bands were polymorphic. Among cultivars Nei's gene diversity ranged in the interval 0.1344-0.0313, Shannon's information index was $0.2022-0.0449$. An analysis of molecular variance $(A M O V A)$ showed a significant genetic diversity among populations $\left(\mathrm{Phi}_{\mathrm{PT}}=0.684, p<0.01\right)$. Unweighted pair group with arithmetic mean (UPGMA) cluster analysis dendrogram generated on the basis of 73 polymorphic RAPD bands showed a clear separation of all analysed cultivars to different clusters. Dendrogram constructed using five morphological traits divided 11 oilseed rape cultivars into two clusters with one stand-alone cultivar 'DK Secure'. No significant correlation of genetic diversity with morphological traits was obtained. A strong and significant correlation between the oilseed rape overwintering capability and the number of polymorphic loci was obtained only in 2008-2009 season $(r=0.81, p=0.03)$.
\end{abstract}

Key words: Brassica napus, genetic variability, morphological traits, RAPD.

\section{Introduction}

The growing conditions for winter oilseed rape in Lithuania are changing because of the fluctuating winter temperatures. Hard winters are critical for most winter oilseed rape cultivars - many farmers in Lithuania suffer loss of their crops because of mild autumns and hard winters. As a result, growers' major concern is good cold tolerance and yield. When biennial plants find themselves in low, non-freezing temperatures - they acclimate to cold undergoing genetic, morphological and physiological changes and therefore gaining freezing tolerance (Savitch et al., 2005). Low temperatures are very important for plant growth and survival, during autumn period plants acclimate and achieve better frost tolerance (Anurag et al., 2004). During autumnal growth and cold acclimation periods many plant growth, development and physiological changes take place (Novickienè et al.,
2004; Velička et al., 2005). When plants are long-term cold acclimated, some morphological changes occur - they become dwarf, their leaves get thicker because of increased mesophyll cell size, specific leaf weight, decrease of leaf water content, etc. (Savitch et al., 2005). Therefore low temperatures have an important influence on the survival of plants and can change the peculiarities of plant growth and productivity - these changes occur due to the changes in gene expression (Kurbidaeva, Novokreshchenova, 2011; Lee, Tomashow, 2012).

Sufficient genetic diversity is very important for plants to survive in changing climate conditions, withstand diseases and pests, etc. Many molecular markers are used for studies of genetic diversity in Brassica: restriction fragment length polymorphism (RFLP), amplified fragment length polymorphism (AFLP), random 
amplified polymorphic DNA (RAPD), simple sequence repeats (SSR), sequence-related amplified polymorphism (SRAP), etc. (Halldén et al., 1994; Riaz et al., 2001; Negi et al., 2004; Hasan et al., 2006). RAPD markers are used for genetic diversity analysis of many plant species (Galović et al., 2006; Vyšniauskienè et al., 2011; Zybartaite et al., 2011; Vyšniauskienè et al., 2013). RAPD markers were used for evaluation of genetic variability in some Brassica species (Dulson et al., 1998; Yu et al., 2005). Sobotka et al. (2004) concluded that AFLP method detected polymorphisms in oilseed rape cultivars more efficiently than either RAPD or SSR methods, but also stated the importance to detect informative markers and confirmed that the results obtained by different marker systems were often similar. The main disadvantage of RAPD method is often reported to be a low reproducibility, but improved laboratory techniques and more exact band scoring help upgrading the poor reproducibility in RAPD analyses (Ivanova et al., 2008). Genetic diversity is best estimated if other markers - agro-morphological, biochemical are also studied (Yu et al., 2005; Galović et al., 2006).

Our previous studies of the genetic diversity of winter oilseed rape were concentrated on the search of suitable primers - we have screened twenty primers for their ability to produce polymorphic patterns (Jodinskiene et al., 2008; Paulauskas et al., 2008). Seven different winter oilseed rape cultivars grown by individual farmers in three different regions in Lithuania were analysed by RAPD method and a significant genetic variation was detected among and within cultivars; however, UPGMA dendrodrams clusters did not reflect the geographic regions of oilseed rape populations (Jodinskienè et al., 2008; Paulauskas et al., 2008).

The aim of the current work was to: 1) analyze morphological traits of 11 cultivars of winter oilseed rape grown in experimental fields; 2) assess the genetic diversity of the cultivars using RAPD markers; 3) determine the correlation among phenotypic variation, DNA polymorphism and good overwintering characteristics of winter oilseed rape.

\section{Materials and methods}

Plant material. Eleven winter oilseed rape (Brassica napus L. var. oleifera Metzg.) cultivars: 'DK Secure', 'Sunday', 'SW Celsius', 'Titan', 'Visby', 'Hornet', 'Kronos', 'Vision', 'Libea', 'Silvia', 'Valesca' were examined. They were grown during 2008-2009 and 2009-2010 in experimental fields at the Institute of Agriculture, Lithuanian Research Centre for Agriculture and Forestry (Kèdainiai district), common cultivation practices were applied. The plot of each cultivar was 10 $\times 2.5 \mathrm{~m}$. The development of the plants in the autumns of 2008 and 2009 was examined in four replicates; ten plants per each replication were analyzed. In the autumns of 2008 and 2009, after the vegetation period was finished ( $30^{\text {th }}$ of November) analyses of oilseed rape cultivars' developmental stage were accomplished. Five main morphological traits were estimated: stand density, height of growth point from the soil surface, thickness of root neck, the number of developed leaves per plant as well as the number of plants survived in spring. For molecular analyses ten to fourteen samples of leaves from individual plants of each cultivar were collected in spring 2010 within each cultivar. Leaves of plants were cut, sealed in separate bags, cooled, transferred to the laboratory, and frozen under $-20^{\circ} \mathrm{C}$.

Deoxyribonucleic acid (DNA) extraction. DNA was extracted from frozen $\left(-20^{\circ} \mathrm{C}\right)$ leaves using genomic DNA extraction kit K0512 (Fermentas Thermo Scientific, Lithuania). The concentration of DNA was estimated with a spectrophotometer "Bio Photometer" (Eppendorf, Germany). DNA was diluted up to $100 \mathrm{ng} \mu \mathrm{l}^{-1}$ for use in PCR.

Polymerase chain reaction (PCR) conditions. DNA amplification was carried out in PCR tubes, total reaction volume was $25 \mu \mathrm{l}$. DNA amplification was performed using a thermocycler (Eppendorf, Germany) programmed to 1 cycle at $94^{\circ} \mathrm{C}$ for $1 \mathrm{~min} 30 \mathrm{~s}$, following 45 cycles at $94^{\circ} \mathrm{C}$ for $30 \mathrm{~s}$, at $32-36^{\circ} \mathrm{C}$ for $35 \mathrm{~s}$, at $72^{\circ} \mathrm{C}$ for $1 \mathrm{~min}$; final extension at $72^{\circ} \mathrm{C}$ for $2 \mathrm{~min}$; and held at $4^{\circ} \mathrm{C}$. Primers used were synthesized by Fermentas Thermo Scientific (Lithuania). Twelve primers were screened for their ability to produce polymorphic patterns: 222,250 , 268, 269, 340, 474, 516, 563, OPA 1, OPA 4, OPA 9 and OPA 11 (Dulson et al., 1998; Paulauskas et al., 2008). Nine of them were selected for further experiments. After amplification, PCR products were separated by electrophoresis in 1.5\% agarose gel. Agarose gel was stained with ethidium bromide and documented under the UV light EASY Win32 (Herolab, Germany). Gene Ruler $^{\mathrm{TM}} 100$ bp DNA Ladder Plus (Fermentas Thermo Scientific, Lithuania) was used as a marker.

Meteorological conditions. During 20082009 and 2009-2010 growing seasons meteorological conditions were different. The temperatures in 20082009 did not differ much from long-term average and winter oilseed rape over wintered successfully. Whereas in January 2010, the mean air temperature was much lower in comparison with January 2009 and was about $12^{\circ} \mathrm{C}$ below zero for six successive days $\left(22^{\text {nd }}-27^{\text {th }}\right.$ of January) (Fig. 1).

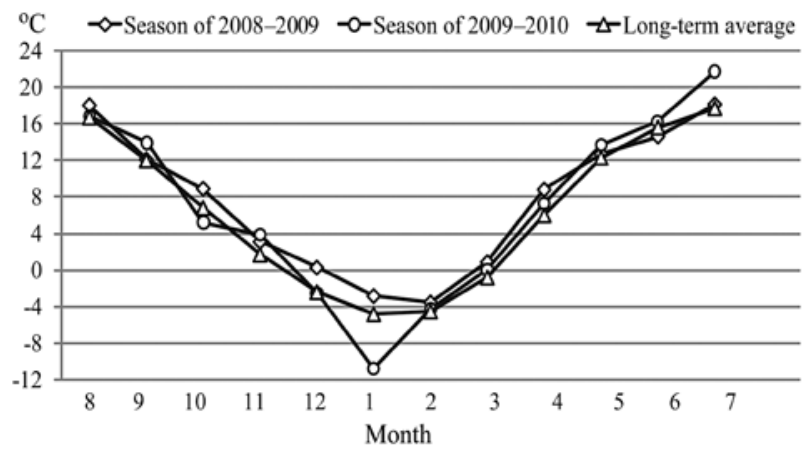

Figure 1. The mean monthly air temperature during the winter oilseed rape growing seasons of 2008-2009 and 2009-2010 (Dotnuva Meteorological Station)

Statistical analysis. The analysis of morphological traits of eleven oilseed rape cultivars was performed by Duncan's multiple range test $(p<0.05)$ (Tarakanovas, Raudonius, 2003). To assess the morphological diversity among oilseed rape cultivars, morphological data were standardized and the Euclidean distance matrix was calculated for the construction of a dendrogram (Fox, 
Rosielle, 1982), using STATISTICA 5. For molecular data analysis, a binary matrix reflecting specific RAPD band presence (1) or absence (0) of a given amplification product in each cultivar was generated (Nei, Li, 1976). The band was assumed to be monomorphic if it was detected in all individuals explored. Genetic distance among individual trees in the study was estimated according to the Nei and $\mathrm{Li}$ (1976) formula from polymorphic RAPD loci. The genetic distance value was calculated using the TREECON for Windows (van de Peer, de Wachter, 1994) and the dendrogram was generated by the unweighted pair group with arithmetic mean (UPGMA) cluster analysis method (Yeh, Boyle, 1997). The confidence of dendrogram branches was determined applying bootstrap analysis $(\mathrm{B}=1000$ replicates). Polymorphic loci percentage, Shannon's information index, Nei's gene diversity and the genetic distance among cultivars were calculated. An analysis of molecular variance $(A M O V A)$ and a principal coordinate analysis (PCA) were accomplished by GenAlEx version 6 software (Peakall, Smouse, 2006).

\section{Results and discussion}

Analysis of morphological traits. The country of origin of most of the analyzed cultivars of winter oilseed rape was Germany, except for 'DK Secure', which was developed in France by "Monsanto SAS", also 'Sunday' and 'SW Celsius', which were bred in Sweden by "SW Seed AB".

The data showed that all oilseed rape cultivars tested differed in plant development in the autumn between years 2008 and 2009 (Table 1). The biggest difference was determined in the height of the growing point from the soil surface. In the autumn of 2008, an average height of the oilseed rape growing point from the soil surface was $8 \mathrm{~mm}$, whereas in the autumn of 2009 it was $40.3 \mathrm{~mm}$. The difference of the height of growing point during these two years was about ten times and the reason of such different growth could be seen in the graph of the mean monthly air temperature in 2008-2010 (Fig. 1). The temperature of September in 2009 was several degrees higher than long-term average and the oilseed rape seedlings were growing fast. The oilseed rape developmental stage achieved during autumn can strongly influence the winter survival (Velička et al., 2005). This, apparently, was one of the main factors that led to worse plant wintering during 2009-2010 compared to 2008-2009 seasons. During 2008-2009, all oilseed rape cultivars tested over wintered successfully - from $86.6 \%$ to $99.9 \%$ of plants survived.

In 2009, the height of the growing point of ' $\mathrm{DK}$ Secure' plants at the end of vegetation period was closest to the soil surface as compared with other analyzed cultivars and was less than $30 \mathrm{~mm}$. Whereas the height of the growing point from the soil surface of 'Titan' was $50.8 \mathrm{~mm}$ and was significantly different from the other analyzed cultivars. It was estimated that oilseed rape cultivars with the least height of the growing point from the soil surface over wintered better than the cultivars with the biggest height of the growing point from the soil surface. The highest percentage of successfully overwintered individuals during 2009-2010 season was in the cultivars 'DK Secure', 'Valesca' and 'SW Celsius', while almost all individuals of 'Sunday', 'Titan' and 'Vision' cultivars were winterkilled.

Table 1. The development of plants of different winter oilseed rape cultivars in the autumn and their overwintering during 2008-2009 and 2009-2010 growing seasons

\begin{tabular}{|c|c|c|c|c|c|c|c|c|c|c|}
\hline \multirow{3}{*}{ Cultivar } & \multicolumn{8}{|c|}{ Autumn (GS 16-18) } & \multirow{2}{*}{\multicolumn{2}{|c|}{$\%$ of overwintering }} \\
\hline & \multicolumn{2}{|c|}{$\begin{array}{l}\text { stand density, } \\
\text { plants } \mathrm{m}^{-2}\end{array}$} & \multicolumn{2}{|c|}{$\begin{array}{l}\text { height of the } \\
\text { growing point from } \\
\text { the soil surface } \mathrm{mm}\end{array}$} & \multicolumn{2}{|c|}{$\begin{array}{l}\text { root neck diameter } \\
\qquad \mathrm{mm}\end{array}$} & \multicolumn{2}{|c|}{$\begin{array}{l}\text { average number of } \\
\text { leaves plant }{ }^{-1}\end{array}$} & & \\
\hline & 2008 & 2009 & 2008 & 2009 & 2008 & 2009 & 2008 & 2009 & 2009 & 2010 \\
\hline DK Secure & n.a. & 70.9 & n.a. & $27.5 \mathrm{~h}^{1}$ & n.a. & $7.2 \mathrm{~h}$ & n.a. & $8.6 \mathrm{f}$ & n.a. & $59.5 \mathrm{a}$ \\
\hline Sunday & 85.9 & 101.3 & $9.4 \mathrm{~d}$ & $44.4 \mathrm{c}$ & $5.7 \mathrm{~cd}$ & $8.2 \mathrm{~d}$ & $5.6 \mathrm{e}$ & $9.4 \mathrm{c}$ & $90.9 \mathrm{ab}$ & $1.6 \mathrm{f}$ \\
\hline SW Celsius & 77.8 & 55.8 & $7.8 \mathrm{c}$ & $40.1 \mathrm{~d}$ & $5.6 \mathrm{bcd}$ & $7.4 \mathrm{gh}$ & $5.1 \mathrm{bc}$ & $8.6 \mathrm{f}$ & $91.2 \mathrm{bc}$ & $51.9 \mathrm{~b}$ \\
\hline Titan & 81.4 & 75.0 & $8.9 \mathrm{c}$ & $50.8 \mathrm{a}$ & $5.6 \mathrm{bcd}$ & $8.1 \mathrm{de}$ & $5.2 \mathrm{c}$ & $8.9 \mathrm{~d}$ & $99.9 \mathrm{e}$ & $6.0 \mathrm{e}$ \\
\hline Visby & n.a. & 60.0 & n.a. & $40.0 \mathrm{~d}$ & n.a. & $8.0 \mathrm{de}$ & n.a. & $9.7 \mathrm{~b}$ & n.a. & $36.1 \mathrm{c}$ \\
\hline Hornet & n.a. & 51.7 & n.a. & $31.9 \mathrm{~g}$ & n.a. & $8.3 \mathrm{~cd}$ & n.a. & $10.0 \mathrm{a}$ & n.a. & $38.2 \mathrm{c}$ \\
\hline Kronos & 86.8 & 68.4 & $7.7 \mathrm{bc}$ & $47.5 \mathrm{~b}$ & $5.2 \mathrm{a}$ & 7.8 ef & $4.5 \mathrm{a}$ & $8.6 \mathrm{f}$ & $96.6 \mathrm{de}$ & $20.0 \mathrm{~d}$ \\
\hline Vision & n.a. & 77.5 & n.a. & $44.1 \mathrm{c}$ & n.a. & $8.6 \mathrm{bc}$ & n.a. & $9.3 \mathrm{c}$ & n.a. & $4.7 \mathrm{ef}$ \\
\hline Libea & 83.8 & 79.6 & $7.8 \mathrm{c}$ & $44.0 \mathrm{c}$ & $5.4 \mathrm{ab}$ & $8.4 \mathrm{~cd}$ & $5.4 \mathrm{~d}$ & $9.3 \mathrm{c}$ & $86.8 \mathrm{a}$ & $19.3 \mathrm{~d}$ \\
\hline Silvia & 90.8 & 65.8 & $7.0 \mathrm{a}$ & $37.6 \mathrm{e}$ & $5.8 \mathrm{~d}$ & $7.6 \mathrm{fg}$ & $5.0 \mathrm{~b}$ & $7.7 \mathrm{~g}$ & $89.1 \mathrm{ab}$ & $39.0 \mathrm{c}$ \\
\hline Valesca & 91.3 & 55.8 & $7.3 \mathrm{ab}$ & $35.6 \mathrm{f}$ & $5.5 \mathrm{bc}$ & $9.1 \mathrm{a}$ & $5.0 \mathrm{~b}$ & $8.8 \mathrm{ef}$ & $93.4 \mathrm{~cd}$ & $56.8 \mathrm{a}$ \\
\hline On average & 85.4 & 69.2 & 8.0 & 40.3 & 5.5 & 8.1 & 5.1 & 9.0 & 92.6 & 30.3 \\
\hline
\end{tabular}

Note. n.a. - not assessed; ${ }^{1}$ - values followed by the same lower-case letter in the same column are not significantly different (Duncan multiple range test, $p<0.05$ ).

Therefore severe winter conditions resulted in a very low percent of successfully overwintered oilseed rape plants and in spring of 2010 the samples of survived individuals were collected for genetic analyses.

In order to compare the results of morphometric and genetic analyses the average results of five morphological traits from 2009-2010 season were analysed by applying cluster analysis according to UPGMA and a dendrogram was constructed with STATISTICA 5. The dendrogram divided the cultivars into two clusters with one stand-alone cultivar 'DK Secure', which was one of the best overwintered cultivars during 
2009-2010 season (Fig. 2). The rest of the cultivars formed two groups: the first cluster consisted of 'SW Celsius', 'Valesca', 'Visby', 'Silvia' and 'Hornet', the second cluster included 'Sunday', 'Vision', 'Titan', 'Kronos' and 'Libea'. The first cluster consisted of the oilseed rape cultivars with overwintering ability from $36.1 \%$ to $56.8 \%$, the second cluster consisted of the cultivars which distinguished themselves by a very poor overwintering ability - from $1.6 \%$ to $20 \%$. Three oilseed rape cultivars - 'Libea', 'Sunday' and 'Valesca' were analyzed earlier by Novickienè et al. (2010) and all of them overwintered successfully in the experimental fields near Vilnius during 2007-2008 and 2008-2009 seasons, their overwintering percent was from $64 \%$ to $84 \%$. In our study overwintering of those cultivars during 2008 2009 was also high and varied from $86.8 \%$ to $93.4 \%$. Better overwintering during the same season of the same cultivars in Dotnuva, compared with Vilnius region, could be due to slightly milder winter conditions in the centre of Lithuania - according to air temperature rate, but most likely the main reason was the optimal development of individual plants in the autumn. The winter of 2009-2010 was extremely severe and the overwintering percent was significantly lower. Oilseed rape cultivar 'Sunday' was referred to as resistant to wintering and it accumulated a sufficient amount of proline (partly responsible for cold resistance) (Novickiene et al., 2010). According to our results, during 2008-2009 season the overwintering of 'Sunday' was $90.9 \%$, while the average height of growing point of the plants from the soil surface was $9.4 \mathrm{~mm}$ (the highest among all cultivars tested during 2008-2009). However, 'Sunday' was one of the most winter killed cultivars during 2009-2010 (only single (1.6\%) individuals survived), and the height of its growing point from the soil surface was relatively high - $44.4 \mathrm{~mm}$. Meanwhile 'DK Secure' and 'Valesca', the best overwintered cultivars in our experiment during 2009-2010 could be distinguished for the lowermost height of the growing point of the plants from the soil surface -27.5 and $35.6 \mathrm{~mm}$, respectively. These results confirmed a statement that favourable germination, growth conditions and plant development in the autumn

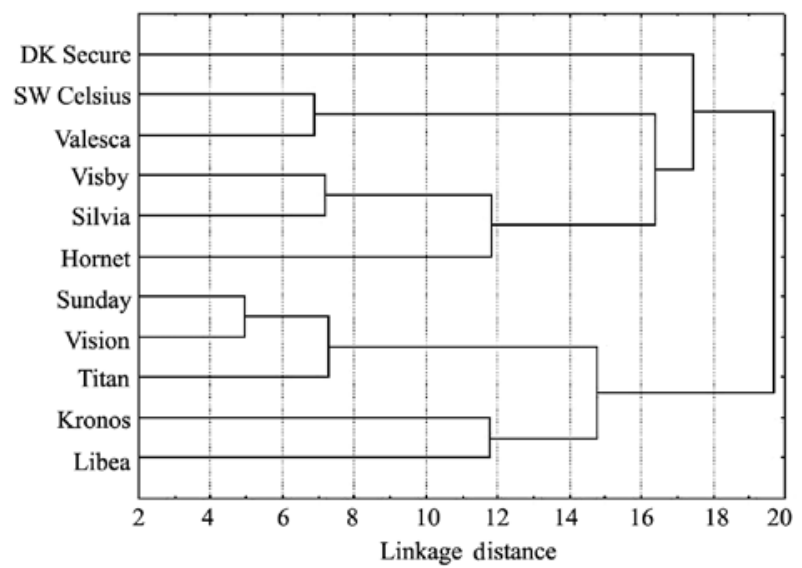

Figure 2. Unweighted pair group with arithmetic mean (UPGMA) dendrogram constructed for eleven winter oilseed rape cultivars based on analysis of five morphological traits applying STATISTICA 5

are very important for oilseed rape plants during the period of winter hardening (Novickienè et al., 2004; Velička et al., 2005).

Genetic diversity. In our previous work, we screened 20 primers for their suitability for analysis of oilseed rape polymorphism. Eight primers 222, 250, 268, $269,340,474,516,563$ were chosen according to Dulson et al. (1998), these primers were proved suitable for oilseed rape polymorphism detection (Jodinskienè et al., 2008; Paulauskas et al., 2008). The other four primers OPA 1, OPA 4, OPA 9, OPA 11 were used earlier in the detection of polymorphism in Brassica napus and other plants (Jodinskienè et al., 2008; Paulauskas et al., 2008). So, 12 RAPD primers were screened for their ability to produce polymorphic patterns, 9 of them were selected as informative ones (Table 2). A total of 84 reproducible RAPD bands were identified among 134 individuals of 11 oilseed rape cultivars using 9 RAPD primers. The size of amplified fragments ranged from 180 to $1500 \mathrm{bp}$. The number of bands per primer ranged from 2 (340) to 14 $(222,563)$, the number of polymorphic bands was $8.11 \pm$ 2.912 per primer (total $9.33 \pm 2.713$ ) (Table 2).

Table 2. Size and number of deoxyribonucleic acid (DNA) bands generated by random amplified polymorphic DNA (RAPD) primers in winter oilseed rape accessions

\begin{tabular}{cccccc}
\hline $\begin{array}{c}\text { RAPD } \\
\text { primer }\end{array}$ & Sequence 5' $\rightarrow 3^{\prime}$, & $\begin{array}{c}\text { Total number } \\
\text { of bands }\end{array}$ & $\begin{array}{c}\text { Polymorphic } \\
\text { RAPD bands }\end{array}$ & $\begin{array}{c}\text { Polymorphism } \\
\%\end{array}$ & $\begin{array}{c}\text { Size of RAPD } \\
\text { bands (bp) }\end{array}$ \\
\hline 222 & 5'-AAGCCTCCCC-3' & 14 & 13 & 92.86 & $300-1500$ \\
250 & 5'-CGACAGTCCC-3' & 6 & 4 & 66.66 & $550-900$ \\
268 & 5'-CGACAGTCCC-3' & 12 & 12 & 100 & $300-1116$ \\
269 & 5'-CCAGTTCGCC-3' & 5 & 2 & 40 & $480-1500$ \\
340 & 5'-GAGAGGCACC-3' & 2 & 2 & 100 & $250-1000$ \\
474 & 5'-AAGCCTCCCC-3' & 10 & 8 & 80 & $250-1100$ \\
516 & 5'-AGCGCCGACG-3' & 10 & 9 & 90 & $300-1100$ \\
563 & 5'-CGCCGCTCCT-3' & 14 & 13 & 92.86 & $325-1450$ \\
OPA 9 & 5'-GGGTAACGC-3' & 11 & 10 & 90.91 & $180-1500$ \\
Total & & 84 & 73 & & \\
\hline Average & Mean \pm CI & $9.33 \pm 2.713$ & $8.11 \pm 2.912$ & $83.7 \pm 12.661$ & \\
\hline
\end{tabular}

CI - confidence interval; $\mathrm{n}-9, p \leq 0.05$ 
RAPDs were used also by other authors for the evaluation of genetic diversity of oilseed rape -60 to 120 primers were tested, polymorphic bands constituted from $31 \%$ to $76 \%$ (Sobotka et al., 2004). Ahmad et al. (2007) used four RAPD primers for the estimation of genetic polymorphism for $20 \mathrm{~B}$. napus and B. campestris lines and its level was in the range of $21.50 \%$ to $59.41 \%$ and $53.75 \%$ to $60.09 \%$, respectively. These results showed the importance of choosing informative RAPD primers. In the current study which included 11 winter oilseed rape (B. napus) cultivars -73 loci $(83.7 \pm 12.661 \%)$ were polymorphic.

Intra-population variability of $11 \mathrm{~B}$. napus cultivars using 9 RAPD primers is presented in Table 3.
The average percentage of polymorphic loci in the level of population was $25 \pm 5.339 \%$, the average number of polymorphic loci was $21 \pm 4.485$. The highest percentage of polymorphic loci was $39.29 \%$ for 'DK Secure' and the lowest $7.14 \%$ for 'Hornet' (Table 3). A more appropriate measure of genetic variation is average heterozygosity or Nei's gene diversity. Higher heterozygosity values indicate broader genetic diversity. In the present study, the highest Nei's genetic diversity was found within the cultivar 'DK Secure' $(0.1344)$ and lower genetic diversity was found for the cultivar 'Hornet' (0.0313), Shannon's information index ranged from 0.2022 to 0.0449 in the same cultivars, respectively (Table 3 ).

Table 3. Genetic parameters of winter oilseed rape cultivars according to 9 random amplified polymorphic DNA (RAPD) primers

\begin{tabular}{|c|c|c|c|c|}
\hline Cultivar & $\begin{array}{c}\text { Polymorphism } \\
\%\end{array}$ & $\begin{array}{c}\text { Number of polymorphic } \\
\text { loci }\end{array}$ & Nei's gene diversity & $\begin{array}{c}\text { Shannon's information } \\
\text { index }\end{array}$ \\
\hline DK Secure & 39.29 & 33 & 0.1344 & 0.2022 \\
\hline Sunday & 27.38 & 23 & 0.0901 & 0.1357 \\
\hline SW Celsius & 32.14 & 27 & 0.1015 & 0.1533 \\
\hline Titan & 23.81 & 20 & 0.0834 & 0.1243 \\
\hline Visby & 17.86 & 15 & 0.0651 & 0.0964 \\
\hline Hornet & 7.14 & 6 & 0.0313 & 0.0449 \\
\hline Kronos & 21.43 & 18 & 0.0744 & 0.1107 \\
\hline Vision & 16.67 & 14 & 0.0624 & 0.0924 \\
\hline Libea & 34.52 & 29 & 0.1046 & 0.1611 \\
\hline Silvia & 27.38 & 23 & 0.0896 & 0.1362 \\
\hline Valesca & 27.38 & 23 & 0.1060 & 0.1558 \\
\hline Mean \pm CI & $25 \pm 5.339$ & $21 \pm 4.485$ & $0.086 \pm 0.016$ & $0.1285 \pm 0.008$ \\
\hline
\end{tabular}

$\mathrm{CI}$ - confidence interval; $\mathrm{n}-11, p \leq 0.05$

The highest amount of population-specific bands was identified in the cultivar 'DK Secure' -5 private bands $\left(268_{650}\right.$, OPA $\left.9_{800},{ }^{250} 1200,1500\right)$, in cultivar 'SW Celsius' -3 private bands $\left(222_{300}, 474_{620}\right.$, OPA $\left.9{ }_{600}\right), 2$ private bands were found in cultivars 'Titan' and 'Libea'. Dulson et al. (1998) analyzed in detail some of the primers used for bulked DNA samples for RAPD DNA fingerprinting in $B$. napus cultivars. Some of the markers mentioned were also found in our analysis - according to Dulson et al. (1998) 250.0825 was invariant in abundance - it had the same invariance in all tested cultivars except for 'DK Secure' where it was absent. 269.0600 was detected in three of the four tested cultivars (Dulson et al., 1998), and the same was detected in all 11 tested cultivars; some markers - 222.1500, 474.0700, 268.0600 were amplified only in some of the tested winter oilseed rape cultivars.

Genetic structure of oilseed rape cultivars. On the basis of 73 polymorphic RAPD bands an UPGMA dendrogram was generated using the TREECON for Windows (Van de Peer, De Wachter, 1994) (Fig. 3). Dendrogram showed the relationships between individuals and cultivars. The results indicated that all individuals from eleven oilseed rape cultivars were genetically different, except for the cultivar 'Hornet' which was almost monomorphic. The dendrogram consisted of three main clusters, also it showed a clear separation of all eleven cultivars to different subclusters: cultivars of 'Hornet', 'SW Celsius', 'Sunday', 'Kronos' formed one group, 'Titan', 'Visby', 'Vision', 'Libea' formed second group and 'Silvia', 'Valesca', 'DK Secure' belonged to a third group. As a result, 'DK Secure' separated from other cultivars, 'Sunday' and 'SW Celsius' showed closer relationship with lowest genetic distance (0.0989). The greatest genetic distance $(0.3068)$ was observed between 'DK Secure' and 'Titan'.

Results of principal component analysis accomplished by GenAlEx confirmed those of cluster analysis. Principal component (PC) analysis indicated that $\mathrm{PC} 1$ accounted for $23.66 \%$ of the total variation and PC2 accounted for $20.2 \%$ of the variation (Fig. 4). In the present study, according to PCA analysis, the cultivars of B. napus were grouped into the same three distinct groups: 'Hornet', 'SW Celsius', 'Sunday', 'Kronos' formed one group, 'Titan', 'Visby', 'Vision', 'Libea' formed a second group and 'Silvia', 'Valesca', 'DK Secure' belonged to a third group.

An AMOVA analysis was performed in GenAlEx and revealed that $68 \%$ of the total genetic diversity occurred among the cultivars $\left(\mathrm{Phi}_{\mathrm{PT}}=0.684\right)$ and $32 \%$ among individuals within cultivars (Fig. 4, Table 4). All $A M O V A$ variation was highly significant $(p<0.01)$.

We searched for a correlation between winter oilseed rape morphological traits and genetic diversity. No significant correlation of genetic diversity with morphological traits was obtained by applying STATISTICA 5. Only one strong and significant correlation between the winter oilseed rape overwintering capability and the number of polymorphic loci was calculated $(r=0.81, p=0.03)$. Yu et al. (2005) detected no significant correlation among oilseed rape protein, RAPD and morphological markers. A lack of or only a weak correlation between morphological traits and RAPD 


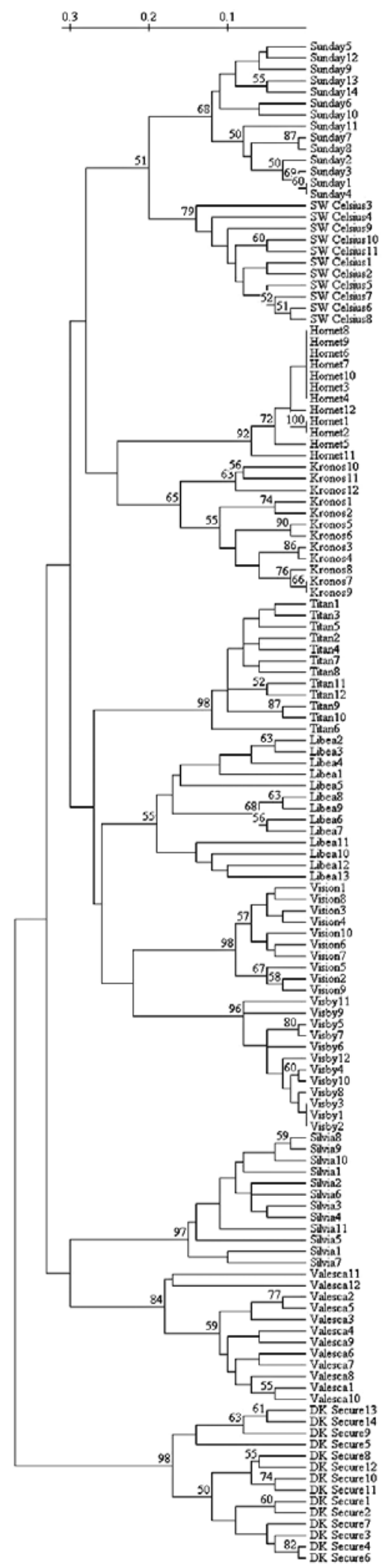

Note. Numbers above dendrogram branches represent bootstrap values (100 times resampling analysis); only values $>50 \%$ are presented.

Figure 3. Unweighted pair group with arithmetic mean (UPGMA) dendrogram based on Nei's genetic distances obtained for 134 winter oilseed rape individuals using random amplified polymorphic DNA (RAPD) markers applying the TREECON for Windows

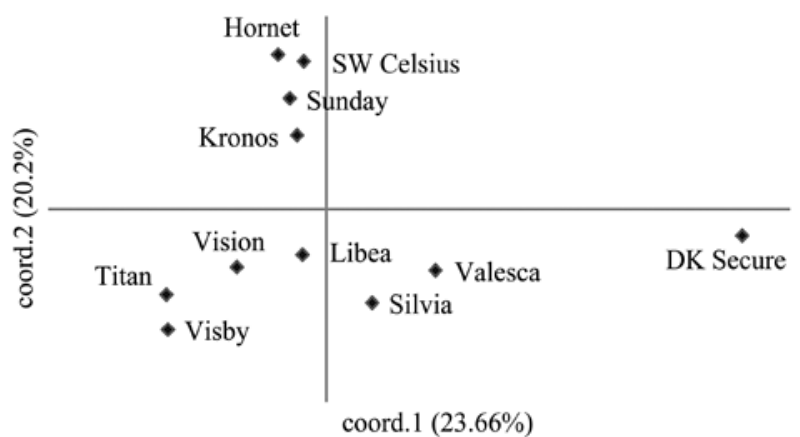

Figure 4. Association among eleven winter oilseed rape cultivars revealed by principal coordinates analysis applying GenAlEx version 6 software

markers was also established by other authors (Patamsyte et al., 2008). This can be explained by the use of the quantitative morphological markers, which are more affected by the environment than molecular markers, the latter being more phenotypically neutral (Patamsyte et al., 2008). Also, similar phenotypes could form from different genotypes, and morphologically similar plants may contain different gene pools (Khan et al., 2009). Our results demonstrated that genetic polymorphism between 11 tested winter oilseed rape cultivars was high. All cultivars separated into different clusters, constituting three distinct groups. In our previous work on the polymorphism of winter oilseed rape we did not succeed in distinguishing five cultivars to different clusters despite the fact that the mentioned cultivars were grown by individual farmers in the regions of Lithuania being apart from one another more than $100 \mathrm{~km}$ (Jodinskiene et al., 2008). While testing 11 cultivars grown in experimental fields in the same conditions, the variation within cultivars was not high, but the highest percentage of variation was detected between cultivars. The current analysis showed that cultivars from the same country of origin - 'Sunday' and 'SW Celsius' (developed in Sweden) were separated into different clusters according to the morphological traits, but genetically they were the closest.

The significant correlation between the winter oilseed rape overwintering capability and the number of polymorphic loci was obtained only in 2008-2009 ( $r=$ $0.81, p=0.03$ ). But the cultivar 'DK Secure' (created in France) was the most exceptional in morphological traits and in the genetic analysis - the cultivar had the greatest level of DNA polymorphism, the lowermost height of the growing point from the soil surface and meanwhile the best overwintering capability during severe winter of 2009-2010. Also 'DK Secure' and 'SW Celsius' were two cultivars with the best overwintering percents -59.5 and 51.9 , and the highest amount of population-specific bands were identified in the cultivar 'DK Secure' -5 private bands $\left(268_{650}\right.$, OPA $\left.9_{800,850,1200,1500}\right)$, and in cultivar ' $\mathrm{SW}$ Celsius' -3 private bands $\left(222_{300}, 474_{620}\right.$, OPA $\left.9{ }_{600}\right)$.

Although the comparison of morphological and molecular variation did not reveal any significant correlation, some relation among DNA polymorphism, height of the growing point and overwintering capability does exist. This relation could be revealed better when applying more different informative primers and more morphological traits. 
Table 4. Analysis of molecular variance $(A M O V A)$ for 134 winter oilseed rape individuals sampled from eleven cultivars using 73 polymorphic random amplified polymorphic DNA (RAPD) bands

\begin{tabular}{cccccccc}
\hline $\begin{array}{c}\text { Source of } \\
\text { variation }\end{array}$ & d.f. & SS & MS & $\begin{array}{c}\text { Variance } \\
\text { component }\end{array}$ & $\begin{array}{c}\text { Total variance } \\
\%\end{array}$ & $p$-value & Phi $_{\text {PT }}$ \\
\hline $\begin{array}{c}\text { Among } \\
\text { cultivars }\end{array}$ & 10 & 990.453 & 99.045 & 7.839 & 68 & \\
$\begin{array}{c}\text { Within } \\
\text { cultivars }\end{array}$ & 123 & 446.219 & 3.628 & 3.628 & 32 & 0.010 & 0.684 \\
\hline Total & 133 & 1436.672 & 102.673 & 11.467 & 100 & & \\
\hline
\end{tabular}

d.f. - degree of freedom, $\mathrm{SS}$ - sum of squares, $\mathrm{MS}$ - mean squares, $p$ - level of significance, $\mathrm{Phi}_{\mathrm{PT}}$ - index for genetic differentiation among populations

\section{Conclusions}

1. Unweighted pair group with arithmetic mean (UPGMA) dendrogram constructed using five morphological traits divided eleven winter oilseed rape cultivars into two clusters with one stand-alone cultivar 'DK Secure', which was one of the best overwintered cultivars during 2009-2010 season. The first cluster consisted of 'SW Celsius', 'Valesca', 'Visby', 'Silvia' and 'Hornet', with overwintering ability from $36.1 \%$ to $56.8 \%$, the second cluster included 'Sunday', 'Vision', 'Titan', 'Kronos' and 'Libea', with overwintering ability from $1.6 \%$ to $20 \%$

2. UPGMA dendrogram generated on the basis of 73 polymorphic random amplified polymorphic DNA (RAPD) bands consisted of three main clusters, it revealed separation of all eleven cultivars to different subclusters: 'Hornet', 'SW Celsius', 'Sunday', 'Kronos' formed one group, 'Titan', 'Visby', 'Vision', 'Libea' formed a second group and 'Silvia', 'Valesca', 'DK Secure' belonged to a third group. According to principal coordinate analysis (PCA), the cultivars of Brassica napus were grouped into the same three distinct groups.

3. No significant correlation of genetic diversity with morphological traits was obtained by applying STATISTICA 5. The only significant correlation was obtained between the overwintering capability and the number of polymorphic loci in 2008-2009 $(r=0.81, p=0.03)$.

\section{Acknowledgements}

This research was funded by a grant No. PBT05/2010 from the Research Council of Lithuania.

Received 09082012

Accepted 26082013

\section{References}

Ahmad N., Munir I., Khan I. A., Ali W. 2007. PCR based genetic diversity of rapeseed germplasm using RAPD markers. Biotechnology, 6: 334-338 http://dx.doi.org/10.3923/biotech.2007.334.338

Anurag A. A., Conner J. K., Stinchcombe J. R. 2004. Evolution of plant resistance and tolerance to frost damage. Ecology Letters, 7 (12): 1199-1208 http://dx.doi.org/10.1111/j.1461-0248.2004.00680.x

Dulson J., Kott L. S., Ripley V. L. 1998. Efficacy of bulked DNA samples for RAPD DNA fingerprinting of genetically complex Brassica napus cultivars. Euphytica, 102: 65-70 http://dx.doi.org/10.1023/A:1018378304701

Fox P. N., Rosielle A. A. 1982. Reducing the influence of environmental main-effects on pattern analysis of plant breeding environments. Euphytica, 31: 645-656 http://dx.doi.org/10.1007/BF00039203
Galović V., Mladenović S. D., Navalušić J., Zlokolica M. 2006. Characterization methods and fingerprinting of agronomicaly important crop species. Genetika, 38 (2): 83-96 http://dx.doi.org/10.2298/GENSR0602083G

Halldén C., Nilsson N. O., Rading I. M., Säll T. 1994. Evaluation of RFLP and RAPD markers in comparison of Brassica napus breeding lines. Theoretical and Applied Genetics, 88: 123-128 http://dx.doi.org/10.1007/BF00222404

Hasan M., Seyis F., Badani A. G., Pons-Kühnemann J., Friedt W., Lühs W., Snowdon R. J. 2006. Analysis of genetic diversity in the Brassica napus L. gene pool using SSR markers. Genetic Resources and Crop Evolution, 53 (4): 793-802 http://dx.doi.org/10.1007/s10722-004-5541-2

Ivanova P., Peykov S., Dimitrova A., Dimov S. G. 2008. Molecular typing by genus-specific PCR and RAPD profiling ofdiverse Lactobacillus delbrueckiistrains isolated from cow, sheep and buffalo yoghurts. Biotechnology and Biotechnological Equipment, 22 (2): 748-753

Jodinskienė M., Paulauskas A., Žukauskienè J. 2008. Investigations of oilseed rape (Brassica napus L.) genetic diversity by molecular methods. Biologiia. 54: 238-241 $\mathrm{http} / / / \mathrm{dx}$. doi.org/10.2478/v10054-008-0049-x

Khan M. A., Witzke-Ehbrecht S., Maass B. L., Becker H. C. 2009. Relationships among different geographical groups, agro-morphology, fatty acid composition and RAPD marker diversity in safflower (Carthamus tinctorius). Genetic Resources and Crop Evolution. 56 (1): 19-30 http://dx.doi.org/10.1007/s10722-008-9338-6

Kurbidaeva S., Novokreshchenova M. G. 2011. Genetic control of plant resistance to cold. Russian Journal of Genetics, 47 (6): 646-661 http://dx.doi.org/10.1134/S1022795411050115

Lee C. M., Thomashow M. F. 2012. Photoperiodic regulation of the C-repeat binding factor (CBF) cold acclimation pathway and freezing tolerance in Arabidopsis thaliana. Proceedings of the National Academy of Sciences of the United States of America, 109 (37): 15054-15059 http://dx.doi.org/10.1073/pnas.1211295109

Negi M. S., Sabharwal V., Bhat S. R., Lakshmikumaran M. 2004. Utility of AFLP markers for the assessment of genetic diversity within Brassica nigra germplasm. Plant Breeding. 123: 13-16 http://dx.doi.org/10.1046/j.0179-9541.2003.00926.x

Nei M., Li W., 1976. Mathematical model for studying genetic variation in terms of restriction endonucleases. Proceedings of the National Academy of Sciences of the United States of America. 76: 5269-5273 http://dx.doi.org/10.1073/pnas.76.10.5269

Novickiené L., Gavelienė V., Miliuvienè L., Brazauskienė I., Kazlauskienė D., Pakalniškytė L. 2004. New factors in winter rape technology. Biologija, 2 (2): 91-94

Novickienè L., Gavelienẻ V., Miliuvienė L., Kazlauskienė D., Pakalniškytė L. 2010. Comparison of winter oilseed rape varieties: cold acclimation, seed yield and quality. Zemdirbyste-Agriculture, 97 (3): 77-86

Patamsytė J., Žvingila D., Labokas J., Baliuckas V., Balčiūnienė L., Kleizaitė V., Rančelis V. 2008. Study of genetic diversity in wild raspberry (Rubus idaeus L.) 
germplasm collection using morphological characters and RAPD markers. Biologija, 54 (2): 66-74 http://dx.doi.org/10.2478/v10054-008-0013-9

Paulauskas A., Jodinskienė M., Z̈ukauskienè J. 2008. Identification of suitable RAPD primers to analyse oilseed rape (Brassica napus L.) genetic variability in some regions of Lithuania. Theorie in der Ökologie, 14: 22-26

Peakall R., Smouse P. E. 2006. GENALEX 6: genetic analysis in Excel. Population genetic software for teaching and research. Molecular Ecology Notes, 6: 288-295 http://dx.doi.org/10.1111/j.1471-8286.2005.01155.x

Riaz A., Li G., Quresh Z., Swati M. S., Quiros C. F. 2001. Genetic diversity of oilseed Brassica napus inbred lines based on sequence-related amplified polymorphism and its relation to hybrid performance. Plant Breeding. 120: 411415 http://dx.doi.org/10.1046/j.1439-0523.2001.00636.x

Savitch L. V, Allard G., Seki M., Robert L. S., Tinker N. A., Huner N. P. A., Shinozaki K., Singh J. 2005. The effect of overexpression of two Brassica CBF/DREB1-like transcription factors on photosynthetic capacity and freezing tolerance in Brassica napus. Plant and Cell Physiology. 46: 1525-1539 http://dx.doi.org/10.1093/pcp/pci165

Sobotka R., Dolanská L., Curn V., Ovesná J. 2004. Fluorescencebased AFLPs occur as the most suitable marker system for oilseed rape cultivar identification. Journal of Applied Genetics, 45: 161-73

Tarakanovas P., Raudonius S. 2003. Agronominių tyrimų duomenu statistinè analize taikant kompiuterines programas $A N O V A$, STAT, SPLIT-PLOT iš paketo SELEKCIJA ir IRRISTAT. Lithuanian University of Agriculture, 58 p. (in Lithuanian) van de Peer Y., de Wachter R. 1994. TREECON for Windows: a software package for the construction and drawing of evolutionary trees for the Microsoft Windows environment. Computer Applications in the Biosciences, 10: 569-570

Velička R., Rimkevičienė M., Novickienė L., Anisimovienė N., Brazauskienė I. 2005. Improvement of oil rape hardening and frost tolerance. Russian Journal of Plant Physiology, 52 (4): 473-480 http://dx.doi.org/10.1007/s11183-005-0070-1

Vyšniauskienė R., Rančelienè V., Žvingila D., Patamsytė J. 2011. Genetic diversity of invasive alien species Lupinus polyphyllus populations in Lithuania. ZemdirbysteAgriculture, 98 (4): 383-390

Vyšniauskienė R., Rančelienè V., Patamsytė J., Žvingila D. 2013. High genetic differentiation among wild populations of alien Medicago sativa in Lithuania. Central European Journal of Biology. 8 (5): 480-491 http://dx.doi.org/10.2478/s11535-013-0159-4

Yeh F. C., Boyle T. J. B. 1997. Population genetic analysis of co-dominant and dominant markers and quantitative traits. Belgian Journal of Botany, 129: 157

Yu C. Y., Hu S. W., Zhao H. X., Guo A. G., Sun G. L. 2005. Genetic distances revealed by morphological characters, isozymes, proteins and RAPD markers and their relationships with hybrid performance in oilseed rape (Brassica napus L.). Theoretical and Applied Genetics. 110: 511-518 http://dx.doi.org/10.1007/s00122-004-1858-7

Zybartaite L., Zukauskiene J., Jodinskiene M., Janssens S. B., Paulauskas A., Kupcinskiene E. 2011. RAPD analysis of genetic diversity among Lithuanian populations of Impatiens glandulifera Royle. Zemdirbyste-Agriculture, 98 (4): $391-398$

ISSN 1392-3196 / e-ISSN 2335-8947

Zemdirbyste-Agriculture, vol. 100, No. 4 (2013), p. 409-416

DOI $10.13080 /$ z-a.2013.100.052

\title{
Skirtingai peržiemojusio žieminio rapso (Brassica napus L.) veislių morfologiniai požymiai ir genetinė įvairovè
}

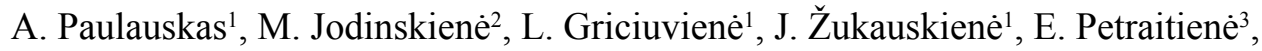 \\ I. Brazauskienè ${ }^{3}$
}

${ }^{1}$ Vytauto Didžiojo universitetas

${ }^{2}$ Gamtos tyrimų centro Botanikos institutas

${ }^{3}$ Lietuvos agrarinių ir miškų mokslų centro Žemdirbystės institutas

\section{Santrauka}

Žieminiai rapsai yra auginami daugelyje šalių dèl vertingo aliejaus ir baltymų. Rapsus auginant šiaurès šalyse viena pagrindinių problemų yra peržiemojimas. Tyrimo tikslas - ištirti morfologinę bei genetinę žieminio rapso (Brassica napus L.) veislių ịvairovę ir ịvertinti koreliaciją tarp fenotipinès ịvairovės, DNR polimorfizmo bei peržiemojimo ypatybių. Siekiant atlikti morfologinę analizę, pasirinkti šie augalų išsivystymo rudenị ir peržiemojimo rodikliai: pasèlio tankumas, augimo pumpuro aukštis nuo dirvos paviršiaus, šaknies kaklelio storis, išsivysčiusių lapų skaičius, peržiemojusių augalų procentas. Žieminio rapso 11 veislių genetinis kintamumas ịvertintas atsitiktinai padaugintos polimorfinès DNR (APPD) metodu, išbandant 14 pradmenų; 9 iš jų buvo polimorfiniai ir naudoti tolesnei analizei. Ištyrus 134 individus identifikuotos 84 APPD atkarpos, iš jų 73 buvo polimorfinès. Tarp veislių Nei genetinè iqvairovè svyravo nuo 0,1344 iki 0,0313, Shannon informacijos indeksas - nuo 0,2022 iki 0,0449. Molekulinès variacijos analizė $(A M O V A)$ parodè didelę genetinę ịvairovę tarp populiacijų $\left(\mathrm{Phi}_{\mathrm{PT}}=0,684, p<0,01\right)$. Pagal 73 polimorfines APPD juostas nubraižyta dendrograma parodè, kad 11 tirtų veislių išsiskyrè i skirtingas grupes. Dendrograma, suformuota pagal 5 morfologinius požymius, 11 tirtų veislių padalijo ị dvi grupes su viena atsiskyrusia veisle 'DK Secure'. Nebuvo aptikta stiprios koreliacijos tarp genetinès ir morfologinès įvairovès. Esminè ir stipri koreliacija nustatyta tik tarp rapsų peržiemojimo ir polimorfinių lokusų skaičiaus 2008-2009 m. $(r=0,81, p=0,03)$.

Reikšminiai žodžiai: APPD metodas, Brassica napus, genetinè ịvairovė, morfologiniai požymiai. 